\title{
The effect of oestradiol-17 $\beta$ on the motility, viability and the acrosomal status of bull sperm
}

\author{
H.B. Çiftci ${ }^{\#}$ and U. Zülkadir \\ Department of Animal Science, School of Agriculture, Selçuk University, 42079 \\ Konya, Turkey
}

\begin{abstract}
The aim of this study was to test the effect of oestradiol-17 $\left(\mathrm{E}_{2}\right)$ on the motility, viability and the acrosomal status of bull sperm in vitro. Pooled semen from Holstein bulls were incubated in the presence of 2 , 4, and $8 \mu \mathrm{g} \mathrm{E} / \mathrm{mL}$ for $24 \mathrm{~h}$. Semen was also incubated in media without $\mathrm{E}_{2}$. During the incubation, the number of motile, viable sperm and the number of sperm possessing lost/damaged acrosomes, cytoplasmic droplets and coiled tails were counted at $0,4,18$ and $24 \mathrm{~h}$ of incubation. Addition of $2 \mu \mathrm{g} \mathrm{E} / \mathrm{mL}$ at $18 \mathrm{~h}$ of incubation increased the total motility over the control. The number of forward progressing sperm was increased by the supplementation of 2 and $8 \mu \mathrm{g} \mathrm{E} / \mathrm{mL}$ over the control group at the $4 \mathrm{~h}$ incubation. Lower doses of $E_{2}(2$ and $4 \mu \mathrm{g} / \mathrm{mL})$ did not affect viability of sperm, but a high dose of $E_{2}(8 \mu \mathrm{g} / \mathrm{mL})$ caused reductions in viability at 4 and $24 \mathrm{~h}$ of incubation. The number of sperm cells with lost acrosomes was significantly high in control group at $24 \mathrm{~h}$ of incubation. The number of sperm cells possessing proximal and distal cytoplasmic droplets and the number of sperm cells bearing coiled tails were not altered by any of the treatments. A small dose of $E_{2}(2 \mu \mathrm{g} / \mathrm{mL})$ had a beneficial effect on the motility and acrosome integrity of bull sperm in vitro. Higher dose of $\mathrm{E}_{2}(8 \mu \mathrm{g} / \mathrm{mL})$ had a detrimental effect on viability.
\end{abstract}

Keywords: Bovine males, estradiol, acrosome, motility, spermatozoa, in vitro incubation

${ }^{\#}$ Corresponding author. E-mail: hbciftci@selcuk.edu.tr

\section{Introduction}

Environmental oestrogens display oestrogen-like activity. Their effects on mammalian sperm function have already been shown (Adeoaya-Osiguwa et al., 2003). Decrease in fertility in aromatase knock-out male mice was severe when the animals were maintained on a soya-free diet (O'Donnell et al., 2001; Robertson et al., 2002). The most potent oestradiol is oestradiol-17 $\left(\mathrm{E}_{2}\right)$ which is synthesized through the aromatization of testosterone by the enzyme $\mathrm{P}_{450}$ aromatase in the testis (Rommerts et al., 1982; Tsai-Morria et al., 1985). It plays an important role in reproduction by regulating the function of the efferent ductules and the epididymis where sperm mature and gain fertilizing ability (Hess et al., 1997; Carreau et al., 2003; Hess \& Carnes, 2004; Lukoseviciute et al., 2005).

The presence of oestrogen receptors (ER $\alpha$ and $\beta$ ) has been shown within the male testes of many species except bulls. Therefore, not enough information is available about the action of oestrogens on bull sperm. It has been reported that oestrogen regulates re-absorption of luminal fluid in the head of the epididymis. Disruption of this function causes sperm to enter the epididymis diluted (Hess et al., 1997). This probably results in morphological abnormalities, leading to infertility. In female animals the concentration of $E_{2}$ increases during the oestrus and follicular rupture. After insemination, sperm would be exposed to $E_{2}$, particularly in tubal fluid. Presence of $E_{2}$ in the female reproductive tract during this time modulates the motility and extent of the viability of sperm (Hunter, 1988).

Motility of sperm is one of the primary mechanisms of sperm transport and traits closely correlated with fertility. Sperm cells can be transported efficiently only in females in oestrus or upon administering $\mathrm{E}_{2}$ to ovariectomized females (Allison \& Robinson, 1972; Bedford, 1972; Hunter, 1988; Boquest \& Summers, 1999). The effect of $E_{2}$ on motility of sperm was studied extensively in humans (Cheng \& Boettcher, 1981; Idaomar et al., 1989; Allag \& Rangari, 1997; Wang et al., 2001; Lambard et al., 2003) and rodents (Bandophyaha et al., 1974; Hawk \& Cooper, 1976; Das, 1977; Rao \& Mathur, 1988; Jin et al., 2005). There are a few reports on the use of $E_{2}$ in in vitro experiments with sheep. This is because the majority of studies concerning the effect of $E_{2}$ in sheep focused on the transfer of sperm in the female reproductive tract (Croker et al., 1975; Hawk \& Cooper, 1975; Hawk et al., 1978). In bulls the majority of in vitro studies focused 
principally on the interaction between $E_{2}$ and oviductal cells and the influence of $E_{2}$ on sperm motility, viability as well as on hormonal secretion (Boquest \& Summers, 1999; Wijayagunawardane et al., 1999; Martinez et al., 2005).

Limited studies have been performed to monitor in vitro the effect of oestrogens on bull sperm. Therefore, the objective of this study was to test the effect of oestradiol-17 $\beta\left(\mathrm{E}_{2}\right)$ on motility, viability and acrosomal status of bull sperm in vitro.

\section{Materials and Methods}

Semen was obtained from two-year old Holstein bulls $(n=3)$ housed at a farm of the School of Agriculture, Selcuk University, Konya, Turkey. The semen was collected five times between 9:00 and 11:00 over a 9-mount time period, using an artificial vagina. Collected semen samples were pooled in a $50 \mathrm{~mL}$ centrifuge tube (C-8296, Sigma, Steinheim, Germany). The tube was brought to the laboratory within $20 \mathrm{~min}$ at $37^{\circ} \mathrm{C}$. Seminal plasma was removed by washing the semen with phosphate buffered saline (PBS, P5493, Sigma-Aldrich, Steinheim, Germany) containing $0.06 \mathrm{mg} / \mathrm{mL}$ penicillin-G (Potassium salt, P7794, SigmaAldrich, St Louis, USA). Washing was done by centrifuging twice at $1500 \mathrm{rpm}$ for $5 \mathrm{~min}$.

Oestradiol-17ß, $1.52 \mathrm{mg}$ (E1024, Sigma-Aldrich, St Louis, USA), was dissolved in ethanol and the final concentration was adjusted to $0.4 \mu \mathrm{g} / \mu \mathrm{L}$ with PBS. Four petri dishes $(35 \mathrm{x} 10 \mathrm{~mm}$, P5112, SigmaAldrich, Steinheim, Germany) were prepared by adding $2.5 \mathrm{~mL}$ of PBS containing washed sperm cells. One petri dish without $\mathrm{E}_{2}$ was kept as control (C). The other dishes were kept as test groups and 2 (T1), 4 (T2) and 8 (T3) $\mu \mathrm{g} \mathrm{E}_{2} / \mathrm{mL}$ were added. After the addition of $\mathrm{E}_{2}$, the dishes were placed in an incubator at $18.5{ }^{\circ} \mathrm{C}$ for $24 \mathrm{~h}$. Then, at 4, 18 and $24 \mathrm{~h}$ all the measurements were conducted by two different observers.

At the beginning of each experiment the number of motile sperm cells was counted, using a Makler counting chamber (Sefi-Medical, Haifa, Israel). Then at 4, 18 and $24 \mathrm{~h}$ of incubation, $2 \mu \mathrm{L}$ of semen samples from each petri dish were transferred to a pre-warmed Makler counting chamber. The numbers of immotile, wriggling, rotating and forward moving sperm cells were counted under a light microscope at 200x magnification in 10 squares of the chamber. For each sample at last 200 sperm cells were counted at 5 different areas of the chamber and the percentages of motile sperm were calculated.

One gram Nigrosin (1.15924, Merck, Darmstadl, Germany) and $6.7 \mathrm{~mL}$ Eosin (Yellow, 45242, Fluka, Steinheim, Germany) was mixed. Then, $6 \mathrm{~mL}$ ultra pure water was added and dissolved for $20 \mathrm{~min}$ in a water bath at $100{ }^{\circ} \mathrm{C}$ and filtered. To the filtered stain, $0.68 \mathrm{~mL}$ of a glucose solution $(100 \mathrm{~g} / \mathrm{L}$ solution, G8644, Sigma-Aldrich, St Louis, USA) was added and rinsed with $6 \mathrm{~mL}$ of tartrate buffer. The stain was placed in a dark glass container and kept at $4{ }^{\circ} \mathrm{C}$. A Nigrosin-Eosin (NE) and Giemsa mixed stain was prepared by mixing $900 \mu \mathrm{L}$ of NE stain with $100 \mu \mathrm{L}$ of Giemsa (Azur eosin methylene blue solution 1.09204, Merck, Darmstadl, Germany). To determine the initial count of morphologically abnormal sperm, slides $(n=4)$ were prepared and stained with NE and NE mixed with Giemsa.

For staining, $100 \mu \mathrm{L}$ semen samples from each petri dish were places in a test tube and fixed with 100 $\mu \mathrm{L}$ formaldehyde (FI/01FS/060929, Kimetsan, Turkey) for $5 \mathrm{~min}$ in a water bath at $37{ }^{\circ} \mathrm{C}$. Then $100 \mu \mathrm{L}$ of the NE stain or the 100 mixed stain $\left(90 \mu \mathrm{L} \mathrm{NE}\right.$ and $10 \mu \mathrm{L}$ Giemsa) were added and left for 10 min at $37^{\circ} \mathrm{C}$. For each tube, two slides were prepared and counted at 100x magnification, using an oil immersion lens under a light microscope (Leica, DM 2500) equipped with a camera (Leica, DFC-280) connected to a computer. The acrosomal membranes were clearly seen (Figure 1).

At $0,4,18$ and $24 \mathrm{~h}$ of incubation the number of live and dead sperm was counted on NE-stained slides using a light microscope under an oil immersion lens and a 100x magnification. Dead sperm cells were differentiated from live ones by their dark appearance. For each slide, 200 - 300 sperm were counted.

The numbers of all other morphologically abnormal sperm cells were counted using an oil immersion lens at 100x magnification under a light microscope connected to the video camera. On the computer screen the number of sperm possessing cytoplasmic droplets, coiled tails, lost and damaged acrosomes were counted at $0,4,18$ and $24 \mathrm{~h}$ of the experiment on both N-E and N-E together with Giemsa stained slides.

Actual counts were analyzed by ANOVA (Randomized block design). Comparisons between individual treatments were tested using the least significant difference by an MSTAT-C statistical programme (Version 1.2., 1988, Michigan State University, East Lansing, MI 48824, USA) at a significance level of $\mathrm{P}<0.05$. 

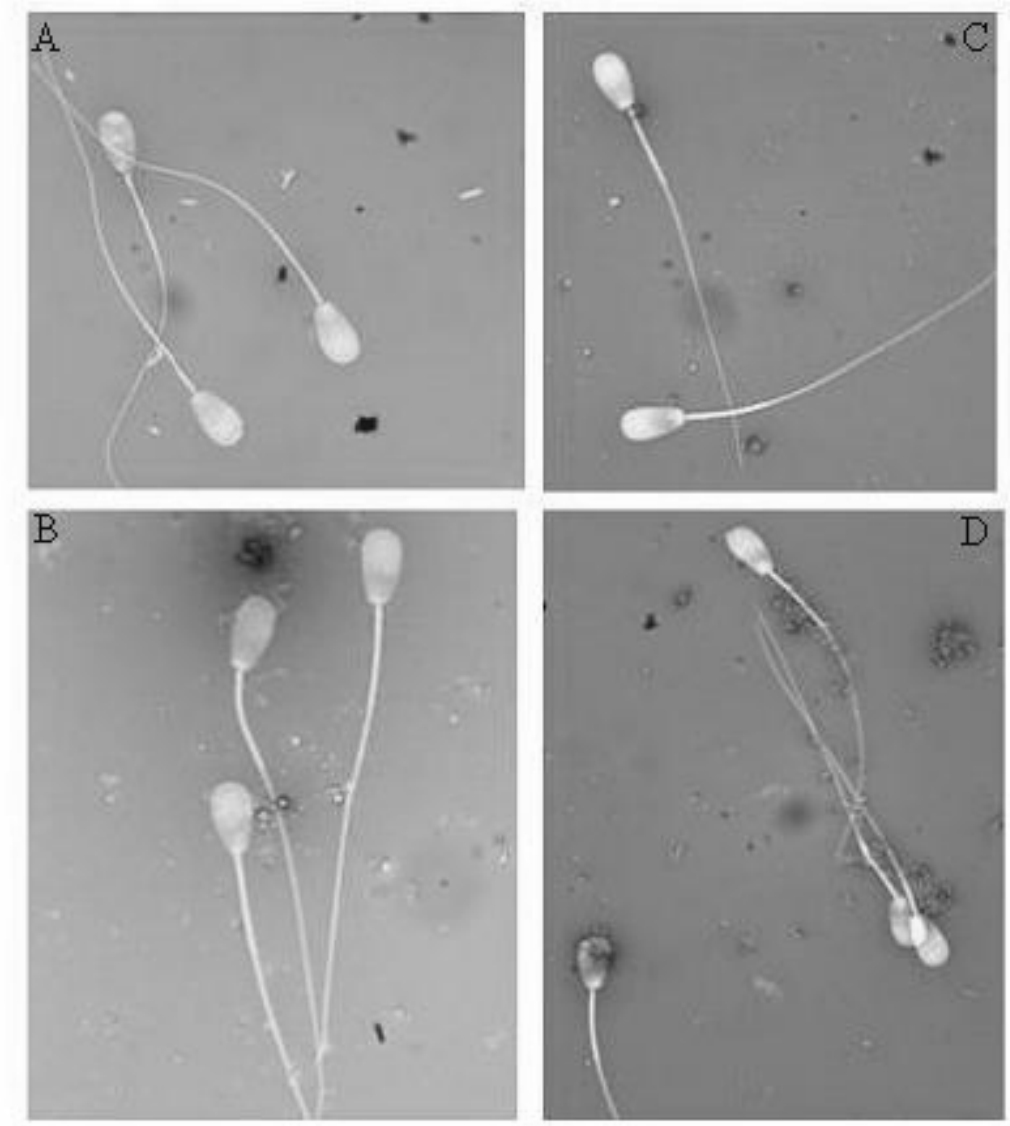

Figure 1 Acrosomal membranes stained with Nigrosin-Eosin (A and B) or Nigrosin-Eosin with Giemsa (C and D).

\section{Results}

Mean ( \pm s.e.) percentages of motile sperm of bull semen incubated for $24 \mathrm{~h}$ in the presence of $\mathrm{E}_{2}$ are displayed in Figure 2. After the addition of $2 \mu \mathrm{g} \mathrm{E} / \mathrm{mL}$ at $18 \mathrm{~h}$ of incubation, the number of total motile sperm was increased as compared to the control group. Differences in total motility were not statistically important at other times. Figure 3 shows that the number of forward progressing sperm was significantly increased $(\mathrm{P}<0.05)$ over the control group at the $4 \mathrm{~h}$ of incubation following the supplementation of 2 and 8 $\mu \mathrm{g} \mathrm{E} \mathrm{E}_{2} / \mathrm{mL}$. Mean ( \pm s.e.) percentages of live and dead sperm displayed on Tables 1 and 2 indicate that lower doses of $E_{2}(2$ and $4 \mu \mathrm{g} / \mathrm{mL})$ did not affect the number of dead and live sperm $(P>0.05)$, but a high dose $\mathrm{E}_{2}$ $(8 \mu \mathrm{g} / \mathrm{mL})$ caused reduction $(\mathrm{P}<0.05)$ of sperm quality at 4 and $24 \mathrm{~h}$ of incubation. Mean ( \pm s.e. $)$ percentages of sperm cells with a lost acrosome during $24 \mathrm{~h}$ of incubation displayed on Table 3 show that sperm cells with lost acrosomes were significantly higher $(\mathrm{P}<0.05)$ in the control group at $24 \mathrm{~h}$ of incubation than in the other treatments. Number of sperm (\%) bearing damaged acrosomes, coiled tail, proximal and distal cytoplasmic droplets during $24 \mathrm{~h}$ are shown in Table 4. It shows that oestradiol did not cause any damage (P $>0.05$ ) to the acrosome. Also, the numbers of sperm possessing proximal and distal cytoplasmic droplets, and the numbers of sperm cells bearing coiled tails were not altered by any of the treatments. 


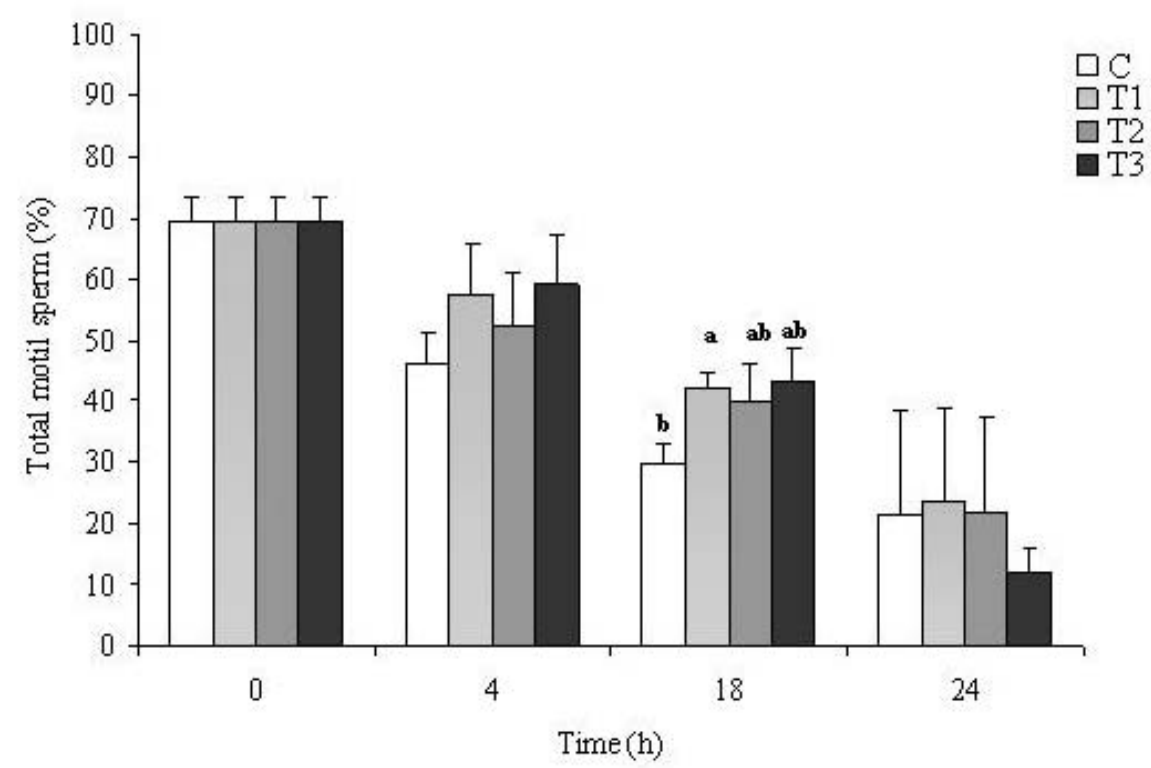

Figure 2 Mean ( \pm s.e.) percentages motile sperm of bull semen incubated for $24 \mathrm{~h}$ at $18.5^{\circ} \mathrm{C}$ with oestradiol-17 $\left(\mathrm{E}_{2}\right)$. C is the control group while T1, T2 and T3 are treatment groups supplemented with $2 \mu \mathrm{g}, 4 \mu \mathrm{g}$ and $8 \mu \mathrm{g} \mathrm{E} / \mathrm{mL}$ respectively.

a, b, ab values with different superscripts differ significantly $(\mathrm{P}<0.05)$.

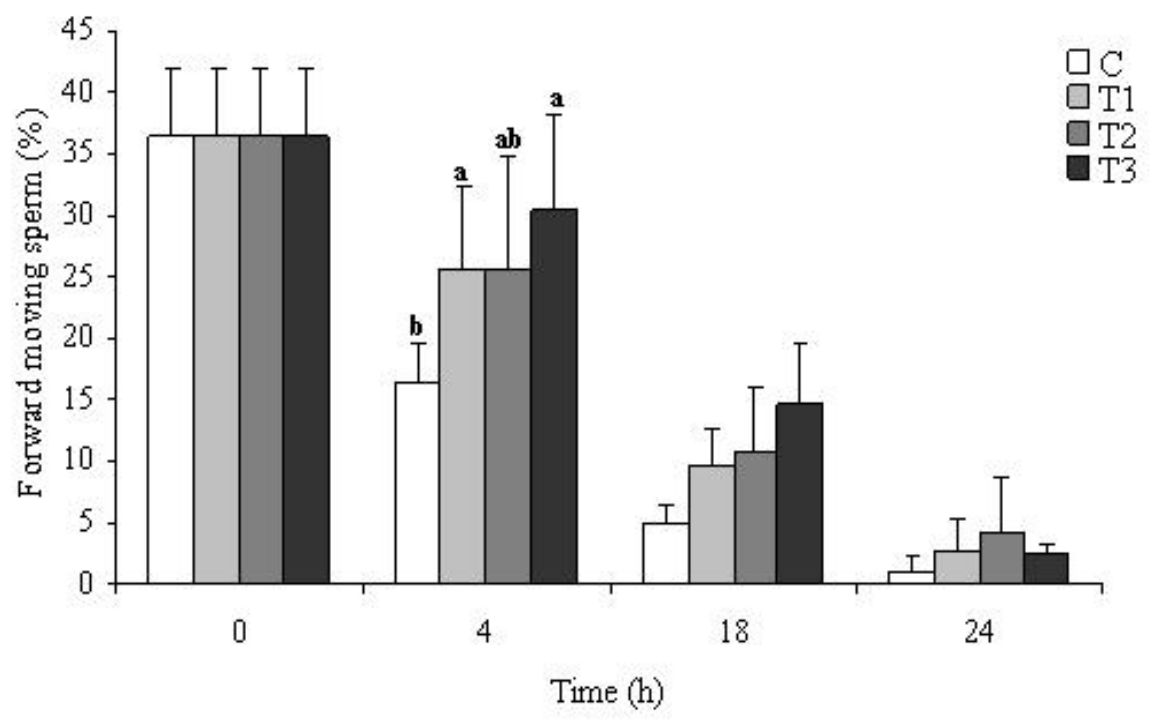

Figure 3 Percentage of forward moving sperm from pulled bull semen incubated with oestradiol-17 $\beta$ $\left(\mathrm{E}_{2}\right)$ for $24 \mathrm{~h}$ at $18.5^{\circ} \mathrm{C}$. C is the control group while T1, T2 and T3 are the test groups supplemented with $2 \mu \mathrm{g}, 4 \mu \mathrm{g}$ and $8 \mu \mathrm{g} \mathrm{E} / \mathrm{mL}$, respectively.

${ }^{\mathrm{a}, \mathrm{b}, \mathrm{ab}}$ values with different superscripts over the columns differ significantly $(\mathrm{P}<0.05)$. 
Table 1 Mean ( \pm s.e.) percentages of live sperm from pooled Holstein semen incubated at $18.5^{\circ} \mathrm{C}$ for $24 \mathrm{~h}$ with oestradiol-17 $\beta\left(\mathrm{E}_{2}\right)$

\begin{tabular}{ccccc}
\hline & \multicolumn{4}{c}{ Percentage live sperm (\%) } \\
\cline { 2 - 5 } Groups & $0 \mathrm{~h}$ & $4 \mathrm{~h}$ & $18 \mathrm{~h}$ & $24 \mathrm{~h}$ \\
\hline $\mathrm{C}$ & $67.65 \pm 3.26$ & $60.63^{\mathrm{a}} \pm 5.74$ & $48.14 \pm 1.76$ & $39.27^{\mathrm{a}} \pm 2.46$ \\
$\mathrm{~T} 1$ & $67.65 \pm 3.26$ & $59.03^{\mathrm{ab}} \pm 4.25$ & $46.40 \pm 4.33$ & $40.92^{\mathrm{a}} \pm 2.29$ \\
$\mathrm{~T} 2$ & $67.65 \pm 3.26$ & $56.79^{\mathrm{ab}} \pm 5.72$ & $46.02 \pm 3.05$ & $42.61^{\mathrm{a}} \pm 1.27$ \\
T3 & $67.65 \pm 3.26$ & $53.11^{\mathrm{bc}} \pm 5.31$ & $49.41 \pm 0.46$ & $31.69^{\mathrm{b}} \pm 4.42$ \\
& & \\
\hline \multicolumn{2}{c}{, b, ab, bc values with different superscripts within a column differ significantly $(\mathrm{P}<0.05)}$. \\
T1 - Test group-1, supplemented with $2 \mu \mathrm{g} \mathrm{E} / \mathrm{mL} ;$ \\
T2 - Test group-2, supplemented with $4 \mu \mathrm{g} \mathrm{E} \mathrm{E}_{2} / \mathrm{mL} ;$ \\
T3 - Test group-3, supplemented with $8 \mu \mathrm{g} \mathrm{E} \mathrm{E}_{2} / \mathrm{mL}$.
\end{tabular}

Table 2 Mean ( \pm s.e.) percentage of dead sperm of pooled Holstein semen incubated at $18.5{ }^{\circ} \mathrm{C}$ for $24 \mathrm{~h}$ with oestradiol-17 $\beta\left(\mathrm{E}_{2}\right)$

\begin{tabular}{ccccc}
\hline \multirow{2}{*}{ Treatments } & \multicolumn{4}{c}{ Percentage of dead sperm (\%) } \\
\cline { 2 - 5 } & $0 \mathrm{~h}$ & $4 \mathrm{~h}$ & $18 \mathrm{~h}$ & $24 \mathrm{~h}$ \\
\hline $\mathrm{C}$ & $32.35 \pm 3.26$ & $39.37^{\mathrm{a}} \pm 5.74$ & $51.86 \pm 1.76$ & $60.73^{\mathrm{a}} \pm 2.46$ \\
T1 & $32.35 \pm 3.26$ & $40.97^{\mathrm{ab}} \pm 4.25$ & $53.60 \pm 4.33$ & $58.08^{\mathrm{a}} \pm 2.29$ \\
T2 & $32.35 \pm 3.26$ & $43.21^{\mathrm{ab}} \pm 5.72$ & $53.98 \pm 3.05$ & $57.39^{\mathrm{a}} \pm 1.27$ \\
T3 & $32.35 \pm 3.26$ & $46.73^{\mathrm{bc}} \pm 5.31$ & $50.59 \pm 0.46$ & $68.31^{\mathrm{b}} \pm 4.42$ \\
\hline
\end{tabular}

\footnotetext{
a, b, ab, bc values with different superscripts within a column differ significantly $(\mathrm{P}<0.05)$.

$\mathrm{T} 1$ - Test group-1, supplemented with $2 \mu \mathrm{g} \mathrm{E}_{2} / \mathrm{mL}$;

$\mathrm{T} 2$ - Test group-2, supplemented with $4 \mu \mathrm{g} \mathrm{E}_{2} / \mathrm{mL}$;

T3 - Test group-3, supplemented with $8 \mu \mathrm{g} \mathrm{E}_{2} / \mathrm{mL}$.
}

Table 3 Mean ( \pm s.e.) percentage sperm cells with lost acrosomes during $24 \mathrm{~h}$ of incubation at $18.5^{\circ} \mathrm{C}$. Data are displayed as mean and standard error

\begin{tabular}{ccccc}
\hline \multirow{2}{*}{ Treatments } & \multicolumn{4}{c}{ Number of sperm with lost acrosomes (\%) } \\
\cline { 2 - 5 } & $0 \mathrm{~h}$ & $4 \mathrm{~h}$ & $18 \mathrm{~h}$ & $24 \mathrm{~h}$ \\
\hline C & $7.52 \pm 1.14$ & $9.06 \pm 0.94$ & $8.88 \pm 0.35$ & $14.25^{\mathrm{a}} \pm 2.57$ \\
T1 & $7.52 \pm 1.14$ & $7.64 \pm 0.94$ & $8.38 \pm 0.30$ & $10.51^{\mathrm{b}} \pm 1.85$ \\
T2 & $7.52 \pm 1.14$ & $10.91 \pm 0.83$ & $10.84 \pm 1.53$ & $10.12^{\mathrm{b}} \pm 2.06$ \\
T3 & $7.52 \pm 1.14$ & $10.02 \pm 2.19$ & $9.06 \pm 1.16$ & $11.43^{\mathrm{ab}} \pm 2.07$ \\
\hline
\end{tabular}

a, b, ab values with different superscripts within a column differ significantly $(\mathrm{P}<0.05)$.

Semen, from three bulls, collected five times $(\mathrm{n}=5)$. C is control group, $\mathrm{T} 1, \mathrm{~T} 2$ and $\mathrm{T} 3$ are the test groups supplemented with $2 \mu \mathrm{g}, 4 \mu \mathrm{g}$ and $8 \mu \mathrm{g}$ oestradiol-17ß $\left(\mathrm{E}_{2}\right)$, respectively.

\section{Discussion}

Upon the addition of $2 \mu \mathrm{g} \mathrm{E} / \mathrm{mL}$, total motility increased at $18 \mathrm{~h}$ of incubation, but was not affected by adding 4 or $8 \mu \mathrm{g} \mathrm{E}_{2} / \mathrm{mL}$. This increase in total motility might be a result of the increase in the number of 
forward progressing sperm cells at $4 \mathrm{~h}$ of incubation. These forward progressing sperm cells at $4 \mathrm{~h}$ were rotating and wriggling at $18 \mathrm{~h}$ of incubation. Here a positive correlation was observed between $\mathrm{E}_{2}$ supplementation and the number motile sperm. A similar positive correlation was reported by Devkota et al. (2008) in post-pubertal Holstein bulls. They investigated the correlation between peripheral $\mathrm{E}_{2}$ concentration and sperm motility in vivo. They reported that sperm motility after collection and after freezing and thawing was correlated positively with the $\mathrm{E}_{2}$ concentration. According to another study, pre-treatment of bovine sperm cells with $\mathrm{E}_{2}$ or oestrous stage-specific serum resulted in a higher percentage of motile sperm after $18 \mathrm{~h}$ in isthmic and after $36 \mathrm{~h}$ in ampullary cultures compared with the control (Boquest \& Summers, 1999). They also concluded that during the pre-ovulatory period when the dominating hormone is $E_{2}$, the bovine oviduct provides an optimal environment for the survival of sperm.

Table 4 Number of sperm (\%) bearing damaged acrosomes, coiled tails, proximal and distal cytoplasmic droplets during $24 \mathrm{~h}$ incubation at $18.5^{\circ} \mathrm{C}$ with oestradiol- $17 \beta\left(\mathrm{E}_{2}\right)$

\begin{tabular}{cccccc}
\hline $\begin{array}{c}\text { Abnormalities } \\
\text { (\%) }\end{array}$ & Treatments & \multicolumn{4}{c}{ Time (h) } \\
\cline { 3 - 6 } & & 0 & 4 & 18 & 24 \\
\hline Damaged & & & & & \\
acrosomes & $\mathrm{C}$ & $5.36 \pm 0.99$ & $7.54 \pm 1.42$ & $6.74 \pm 0.49$ & $10.55 \pm 1.4$ \\
& $\mathrm{~T} 1$ & $5.36 \pm 0.99$ & $6.26 \pm 1.39$ & $6.14 \pm 0.62$ & $12.41 \pm 3.01$ \\
& $\mathrm{~T} 2$ & $5.36 \pm 0.99$ & $8.92 \pm 1.10$ & $7.19 \pm 0.57$ & $11.26 \pm 2.91$ \\
& $\mathrm{~T} 3$ & $5.36 \pm 0.99$ & $9.08 \pm 1.24$ & $6.42 \pm 0.34$ & $9.56 \pm 2.61$ \\
Poximal & & & & \\
cytplasmic & & & & \\
droplets & $\mathrm{C}$ & $2.35 \pm 1.36$ & $1.07 \pm 0.34$ & $0.65 \pm 0.17$ & $0.55 \pm 0.23$ \\
& T1 & $2.35 \pm 1.36$ & $1.53 \pm 0.41$ & $0.64 \pm 0.33$ & $0.44 \pm 0.23$ \\
& T2 & $2.35 \pm 1.36$ & $0.61 \pm 0.29$ & $0.50 \pm 0.36$ & $0.47 \pm 0.32$ \\
Distal & T3 & $2.35 \pm 1.36$ & $0.61 \pm 0.19$ & $0.41 \pm 0.10$ & $0.50 \pm 0.12$ \\
cytplasmic & & & & & \\
droplets & & & & & \\
& $\mathrm{C}$ & $2.18 \pm 0.50$ & $2.13 \pm 1.20$ & $0.32 \pm 0.22$ & $0.63 \pm 0.23$ \\
& T1 & $2.18 \pm 0.50$ & $1.13 \pm 0.52$ & $0.89 \pm 0.26$ & $1.07 \pm 0.76$ \\
Coiled tails & T2 & $2.18 \pm 0.50$ & $1.58 \pm 0.47$ & $0.61 \pm 0.30$ & $1.12 \pm 0.61$ \\
& T3 & $2.18 \pm 0.50$ & $0.95 \pm 0.32$ & $0.39 \pm 0.26$ & $0.58 \pm 0.18$ \\
& C & $1.86 \pm 0.98$ & $0.95 \pm 0.37$ & $1.79 \pm 1.19$ & $0.57 \pm 0.25$ \\
& T1 & $1.86 \pm 0.98$ & $0.62 \pm 0.27$ & $0.73 \pm 0.34$ & $0.38 \pm 0.20$ \\
& T2 & $1.86 \pm 0.98$ & $0.74 \pm 0.25$ & $1.41 \pm 0.93$ & $0.35 \pm 0.20$ \\
& T3 & $1.86 \pm 0.98$ & $0.71 \pm 0.30$ & $1.32 \pm 0.82$ & $0.31 \pm 0.09$
\end{tabular}

Differences are not statistically significant $(\mathrm{P}>0.05)$. $\mathrm{C}$ is control group, T1, T2 and T3: are the test groups supplemented with $2 \mu \mathrm{g}, 4 \mu \mathrm{g}$ and $8 \mu \mathrm{g} \mathrm{E}_{2} / \mathrm{mL}$ respectively.

Similar results to the present study have been reported by Jin et al. (2005), where implanting male hamster with silastic tubes containing either a low or high amount of $E_{2}$ increased sperm motility. The physiological reason behind increased forward motility due to the $\mathrm{E}_{2}$ addition is not presently known. One possibility might be the involvement of cAMP signal transduction pathways. It has been reported that these pathways are involved in activation of sperm motility (Armstrong et al., 1994; Wade et al., 2003). This increase in motility is an important factor affecting fertilization, because high rates of ovum fertilization require efficient transport of sperm from the cervix to the oviducts (Hawk et al., 1978). According to a number of studies, when a specific number of motile sperm cells were added to oocytes, an equal number of oocytes was fertilized (First \& Parrish, 1987; Purdy \& Graham, 2004).

In this study sperm viability was not affected by the supplementation of 2 and $4 \mu \mathrm{g} \mathrm{E} \mathrm{E}_{2} / \mathrm{mL}$, but it was significantly decreased by the addition of $8 \mu \mathrm{g} \mathrm{E}_{2} / \mathrm{mL}$. Higher doses of $\mathrm{E}_{2}$ are detrimental for sperm survival. A study was conducted by Lukoseviciute et al. (2005) to determine the effect of $1 \mu \mathrm{g} \mathrm{E}_{2} / \mathrm{mL}$ on sperm plasma membrane scrambling, capacitation and acrosome reaction of post-thaw bovine sperm. According to the result of their study, the addition of $1 \mu \mathrm{g} \mathrm{E} / \mathrm{mL}$ did not affect sperm viability. In this study even $2 \mu \mathrm{g}$ 
$\mathrm{E}_{2} / \mathrm{mL}$ did not affect sperm viability. Therefore, lower doses of $\mathrm{E}_{2}$ do not alter sperm survival, but higher doses are detrimental.

According to our results, the number of sperm with lost acrosomes is not significantly $(\mathrm{P}>0.05)$ affected by $\mathrm{E}_{2}$ supplementation during $18 \mathrm{~h}$ of incubation, while the number of sperm with lost acrosomes was significantly lower $(\mathrm{P}<0.05)$ in test groups containing 2 and $4 \mu \mathrm{g} \mathrm{E}_{2} / \mathrm{mL}$ compared to the control group at $24 \mathrm{~h}$ of incubation. In the control group, the higher number of sperm with lost acrosomes indicates the presence of a significantly higher number of acrosome-reacted sperm. The addition of $E_{2}$ promoted the sperm to keep acrosomes at an intact state which is necessary for binding of sperm to the zona pellucida, for subsequent fertilization. In the control group the high number of sperm cells with lost acrosomes is not desirable, since sperm with lost acrosomes will no longer be able to interact with an unfertilized oocyte for successful fertilization (Yanagimachi, 1994).

In this study, addition of $E_{2}$ to bull sperm did not cause any significant differences in the number of sperm cells with cytoplasmic droplets. But according to an in vivo study conducted on adult male mice by Cho et al. (2003), a positive effect of oestrogen on sperm maturation in the epididymis was suggested. Our results are different and may be attributed to species difference.

\section{Conclusions}

A lower dose $(2 \mu \mathrm{g} / \mathrm{mL}) \mathrm{E}_{2}$ has a beneficial effect on the motility and the acrosomal integrity of bull sperm in vitro. Sperm survival was not affected by the supplementation of lower doses $(2$ and $4 \mu \mathrm{g} / \mathrm{mL}) \mathrm{E}_{2}$ while a high dose $(8 \mu \mathrm{g} / \mathrm{mL})$ of $\mathrm{E}_{2}$ was detrimental for sperm survival at $24 \mathrm{~h}$ of the incubation.

\section{References}

Adeoya-Osiguwa, S.A., Markoulaki, S., Pocock, V., Milligan, S.R. \& Fraser. L.R., 2003. 17ß-Estradiol and environmental estrogens significantly affect mammalian sperm function. Human Reprod. 18, 100-107.

Allag, I.S. \& Rangari, K., 1997. In-vitro effect of estrogen-antagonist on motility and penetration ability of human spermatozoa. Indian J. Exp. Biol. 35, 822-824.

Allison, A.J. \& Robinson, T.J., 1972. The recovery of spermatozoa from the reproductive tract of the spayed ewe treated with progesterone and oestrogen. J. Reprod. Fertil. 31, 215-224.

Armstrong, V.L., Clulow, J., Murdoch, R.N. \& Jones, R.C., 1994. Intracellular signal transduction mechanisms of rat epididymal spermatozoa and their relationship to motility and metabolism. Mol. Reprod. Dev. 38, 77-84.

Bandopadhyaha, G.P., Das, P. \& Roy, S., 1974. Effect of estradiol-17-beta on spermatozoa of castrated rats. J. Popul. Res. 1, 44-50.

Bedford, J.M., 1972. Sperm transport, capacitation and fertilization. In: Reproductive Biology. Eds Balin, H. \& Glasser, S., Excerpta Medica, Amsterdam. pp. 338-392.

Boquest, A.C. \& Summers, P.M., 1999. Effect of $17 \beta$-oestradiol or oestrous stage-specific cow serum on the ability of bovine oviductal epithelial cell momolayers to prolong the viability of bull spermatozoa. Anim. Reprod. Sci. 57, 1-14.

Carreau, S., Lambard, S., Delalande, C., Denis-Galeraud, I., Bilinska, B. \& Bourguiba, S., 2003. Aromatase expression and role of estrogens in male gonad. Reprod. Biol. Endocrinol. 11, 1-35.

Cheng, C.Y. \& Boettcher, B., 1981. Effects of steroids on the in vitro forward migration of human spermatozoa. Contraception 24, 183-94.

Cho, H.W., Nie, R., Carnes, K., Zhou, Q., Sharief, N.A. \& Hess, R.A., 2003. The antiestrogen ICI 182,780 induces early effects on the adult male mouse reproductive tract and long-term decreased fertility without testicular atrophy. Reprod. Biol. Endocrinol. 18, 1-57.

Croker, K.P., Robinson, T.J. \& Shelton, J.N., 1975. The passage of spermatozoa through the cervix of ovariectomized ewes treated with progesterone and oestrogen. J. Reprod. Fertil. 43, 405-410.

Das, R.P., 1977. Effect of estradiol-17beta and estriol-3-methyl ether on spermatozoa and genital organs of rats. Indian J. Exper. Biol. 15, 16-18.

Devkota, B., Koseki, T., Matsui, M., Sasaki, M., Kanko, E., Miyamto, A., Amaya Montaya, C. \& Miyake, Y-L., 2008. Relationship among age, body weight, scrotal circumference, semen quality and peripheral testesterone and estradiol concentrations in pubertal and post pubertal Holstein bulls. J. Vet. Med. Sci. 70, 119-121. 
First, N.L. \& Parrish, J.J., 1987. In vitro fertilization of ruminants. J. Reprod. Fertil. 34 (Suppl.), 151-165.

Hawk, H.W. \& Cooper, B.S., 1975. Improvement of sperm transport by the administration of estradiol.to estrous ewes. J. Anim. Sci. 41, 1400-1406.

Hawk, H.W. \& Cooper, B.S., 1976. Improvement of sperm transport in estrous rabbits by exogenous estradiol. Biol. Reprod. 15, 402-405.

Hawk, H.W., Conley, H.H. \& Cooper, B.S., 1978. Number of sperm in the oviducts, uterus, and cervix of the mated ewe as affected by exogenous estradiol. J. Anim. Sci. 46, 1300-308.

Hess, R.A. \& Carnes, K., 2004. The role of estrogen in testis and the male reproductive tract: a review and species comparison. Anim. Reprod. 1, 5-30.

Hess, R.A., Bunick, D., Lee, K-H., Bahr, J., Taylor, J.A., Korach, K.S. \& Lubahn, D.B., 1997. A role for oestrogens in the male reproductive system. Nature 390, 509-512.

Hunter, R.H.F., 1988. Transport of gametes, selection of spermatozoa and gamete lifespan in the female tract. In: The Fallopian Tubes, their Role in Fertility and Infertility. Ed. Hunter, R.H.F., Springer Verlag; New York. pp. 53-80.

Idaomar, M., Guerin, J.F., Lornage, J. \& Czyba, J.C., 1989. Stimulation of motility and energy metabolism of spermatozoa from asthenozoospermic patients by 17 beta-estradiol. Arch. Androl. 22, 197-202.

Jin, W., Arai, K.Y., Watanabe, G., Suzuki, A.K. \& Takahashi, S., 2005. The stimulatory role of estrogen on sperm motility in the male Golden Hamster (Mesocricetus auratus). J. Androl. 26, 478-484.

Lambard, S., Galeraud-Denis, I., Bouraima, H., Bourguiba, S., Chocat, A. \& Carreau, S., 2003. Expression of aromatase in human ejaculated spermatozoa: a putative marker of motility. Mol. Hum. Reprod. 9, 114-124.

Lukoseviciute, K., Zilinskas, H. \& Januskauskas, A., 2005. The effect of ostrediol, progesterone and heparin on bovine spermatozoa function after thawing. Reprod. Domest. Anim. 40, 100-107.

Lukoseviciute, K., Bizokas, V., Zilinskas, H. \& Januskauskas, A., 2007. Effect of progesterone and oestradiol on sperm-zona binding and acrosome reaction in bovine spermatozoa after thawing. Reprod. Domest. Anim. 42, 320-325.

Martinez, M.F., Kastelic, J.P., Bó, G.A., Caccia, M. \& Mapletoft, R.J., 2005. Effects of oestradiol and some of its esters on gonadotrophin release and ovarian follicular dynamics in CIDR-treated beef cattle. Anim. Reprod. Sci. 86, 37-52.

O'Donnell, L., Robertson, K.M., Jones, M.E. \& Simpson, E.R., 2001. Estrogen and spermatogenesis. Endoc. Rev. 22, 289-318.

Purdy, P.H. \& Graham, J.K., 2004. Effect of adding cholesterol to bull sperm membranes on sperm capacitation, the acrosome reaction, and fertility. Biol. Reprod. 71, 522-527.

Rao, M.V. \& Mathur, N., 1988. Estrogen induced effects on mouse testis and epididymal spermatozoa. Exp. Clin. Endocrinol. 91, 231-234.

Robertson, K.M., O'Donnell, L., Simpson, E.R. \& Jones, M.E., 2002. The phenotype of the aromatase knockout mouse reveals dietary phytoestrogens impact significantly on testis function. Endocrinology 143, 2913-2921.

Rommerts, F.F.G., De Jong, F.H., Brinkmann, A.O. \& Van der Molen, H.J., 1982. Development and cellular localization of rat testicular aromatase activity. J. Reprod. Fert. 65, 281-288.

Tsai-Morris, C.H., Aquilano, D.R. \& Dufau, M.I., 1985. Cellular localization of rat testicular aromatase activity during development. Endocrinology 132, 1396-1401.

Wade, M.A., Jones, R.C., Murdoch, R.N. \& Aitken, R.J., 2003. Motility activation and second messenger signalling in spermatozoa from rat cauda epididymidis. Reproduction 125, 175-183.

Wang, Y., Storeng, R., Dale, P.O., Abyholm, T. \& Tanbo, T., 2001. Effects of follicular fluid and steroid hormones on chemotaxis and motility of human spermatozoa in vitro. Gynecol. Endocrinol. 15, 286-2892.

Wijayagunawardane, M.P., Miyamoto, A. \& Sato, K., 1999. Prostaglandin E2, prostaglandin F2 alpha and endothelin-1 production by cow oviductal epithelial cell monolayers: effect of progesterone, estradiol 17 beta, oxytocin and luteinizing hormone. Theriogenology 52, 791-801.

Yanagimachi, R., 1994. Mammalian fertilization. In: The Physiology of Reproduction. (2nd ed.). Eds Knobil, J.D. \& Neil, J.D., Raven Pres, New York, USA. pp. 189-317. 